Portland State University

PDXScholar

Women, Gender, and Sexuality Studies Faculty

Publications and Presentations

Women, Gender, and Sexuality Studies

Spring 2013

\title{
"People Don't Attack You If You Dress Fancy": Consuming Femininity in Contemporary China
}

Sally McWilliams

Portland State University, s.mcwilliams@pdx.edu

Follow this and additional works at: https://pdxscholar.library.pdx.edu/wgss_fac

Part of the Gender and Sexuality Commons

Let us know how access to this document benefits you.

Citation Details

McWilliams, S., "'People don't attack you if you dress Fancy': Consuming femininity in contemporary China". Women Studies Quarterly. Vol. 41, pp. 162-183. June 2013.

This Article is brought to you for free and open access. It has been accepted for inclusion in Women, Gender, and Sexuality Studies Faculty Publications and Presentations by an authorized administrator of PDXScholar. Please contact us if we can make this document more accessible: pdxscholar@pdx.edu. 


\section{"People Don't Attack You If You Dress Fancy": Consuming Femininity in Contemporary China}

Sally E. McWilliams

April 2001, Nanjing, PRC: On a bright, sunny spring afternoon I am walking on a section of the Ming dynasty wall in Nanjing and look down to see a dozen heterosexual Chinese couples wearing their Westernized wedding finery, all getting ready for their bridal photo shoots. Juxtaposed against the architectural marker of China's classical military defense, the young women's blindingly white cascades of satin and tulle reflect an aura of transglobal style and desire.

June 2007, Shanghai, PRC: Out for a morning stroll before the heat of the day, I turn a corner and encounter on the sidewalk a line of qipao-clad young waitresses listening attentively to the manager's directives for good service and good business. Through the city's haze I can make out the glitzy high-rise buildings of the Pudong, a symbol of China's rapidly modernizing desires to connect with the world.

Twenty-first-century Chinese cities are spaces not only of architectural hybridity displaying the co-temporality of the dynastic past and the postsocialist future but also locales in which young women perform and negotiate the polyvalent discourses of what it means to be a woman in China. When many students in U.S. college classrooms are asked to offer images of Chinese women, the most frequent (and in some instances pernicious) representations are those of the lotus-footed woman, the state-indoctrinated Maoist revolutionary, the dutiful mother who must adhere to the draconian one-child law, or the young athlete from the dour state-run sports training facilities. ${ }^{1}$ The U.S. popular press has added to this list by 
regularly portraying unisex-uniformed factory workers, female laboring drones whose undifferentiated, unadorned, and exploited female bodies seemingly drive the engine of China's economic growth and power. In many women's studies courses these same bodies become the singular markers of Chinese womanhood, distanced from Western conceptions of femininity. Yet two other figures of femininity have emerged directly from the spaces of consumption generated by the growing Chinese economy: one a fashionable femininity encoded by the white wedding gown of Western modernity, and the other a cultural femininity enrobed in a version of the traditional Chinese qipao. Both forms of femininity are seen across the Chinese metropolitan landscape of restaurants, photography studios, and mega-shopping districts. Arising at the intersections of global market capitalism, nationalism, and heteronormativity, these two garments and those who don them represent a dyad pointing to the complex, overlapping, and even contradictory embodiments of femininity in contemporary China.

Together the white wedding gown and qipao function to delineate the problematic relationship of desire, beauty, and agency in interpreting Chinese female subjectivity. In contrast to the female factory worker's uniform that inscribes her into a monochromatic construction of an asexualized femininity limited to mechanical reproduction in factory settings, these two pieces of female clothing write into the space of Chinese urbanity a femininity that must account for the coexistence of contrasting temporal moments, competing cultural values, and differing sexualities. The qipao represents a stylization of a hypersexualized and depoliticized cultural past visible primarily through the framework of the modern-day service industry, while the white wedding gown symbolizes the emergent present linked to a romanticized ideology of globalization, female worldliness, and heterosexuality. These garments represent what might best be called prefashioned femininities. Each is a type of uniform that marks its wearer within a pre-established and overdetermined definition of femininity. The qipao is literally in service to the hospitality industry as an uniform reliant on the semiotics of a nostalgic Chinese beauty etched with a heightened sexuality and linked to a commercialized, cosmopolitan past (and future). The wedding gown is a signature garment imbricated in a heteronormative transnational system of romance and marriage. Visible in the cities of Shanghai and Nanjing, these prefabricated fashions (qua gendered/feminized uniforms) signal complicated aspects of women's inscription within the sphere of contemporary Chinese modernity. 
In this essay I will examine how the wedding dress and the qipao can be understood as critically interdependent referents of femininity in the grammar of Chinese cosmopolitan fashion, performance, and female subjectivity. My analysis is inspired by interviews with Chinese women that I conducted in 2001, supplemented by conversations and observations made during two teaching stints in China during 2005 and 2007. All those interviewed spoke English; they were either teachers of English to Chinese students or worked with foreign English-speaking students at universities in Shanghai and in Nanjing, a city of more than five million people located eighty-six miles north of Shanghai. The women ranged in age from twenty-four to sixty-four and came from different geographic and socioeconomic backgrounds. While the interviews and subsequent conversations were not focused on questions of fashion or consumerism, these topics emerged during discussions about interviewees' socialization as women, generational differences between themselves and their mothers, and the quality and direction of their lives. These women's insights constitute the basis for my interest in analyzing women's gender formation, identity, and self-presentation in China, a cultural sphere continuing to undergo extreme change.

This study highlights for U.S.-based women and gender studies scholars the importance of displacing preconceived ideas of Chinese women as always already exploited bodies within a globalized national economy such as China's. My analysis underscores how contemporary Chinese femininity is in a state of flux. Critical attention to gender and sexuality through these vestimentary markers of the material culture of modernity provides us with a richer knowledge of how market capitalism and consumption function as crucial aspects in the construction of an uneasy set of Chinese female subjects and their participation in the production of cultural belonging in contemporary China.

\section{Fashioning Femininity}

The appearance of the red qipaos of the service industry and the white wedding gowns of matrimony occurred against a vastly altered cultural and sociopolitical backdrop as the state's relationship to gender and fashion has shifted in the past few decades. During the years of Mao's rule (1949-76), women's fashion was intricately dependent on the nationstate project of creating a powerful proletariat. Strong and hardy young 
women from the working class were the poster girls of the revolution, and femininity was "overruled by the revolutionary spirit" (Wu 2009, 4). The "Iron Girls" of the Cultural Revolution were the most visible symbols of this robust passion for a socialist politics (Jin 2007), and yet this version of femininity and its militarized peasant uniform as fashion was decidedly male centered in inspiration and presentation. ${ }^{2}$ A colleague from Nanjing University-a woman in her midfifties from a working-class family who ultimately earned an advanced degree after having her education interrupted by the Cultural Revolution-reports that the imposed sartorial conformity of the period during Mao's tenure was very hard on young women in particular. If a young woman tried to look different, she was castigated as being a "bad girl" not only in relation to sexual mores but also in terms of social and political nationalist norms. My colleague's memories bespeak the marginalization of femininity at the hands of a Maoist androgynous conformity garbed in masculine trappings; her words align with those of theorist Mayfair Yang, who points out that "gender relations in China in [the Maoist] period were not so much transformed as gender itself declined as a salient category of discourse" $(1999,44)$. Such a decline was tied to the rise of a nationalism premised on heterosexual relations and heteronormativity in service to the nation. As a hallmark of Maoist China, the revolutionary impulse to eradicate previous styles of dress, and especially those deemed bourgeois and feminine, and in their place promote a desexualized uniform became a key strategy to challenge and displace the trappings of gendered forms of class inequality. Rather than lamenting any lost empowerment that might have been attached to the transgression of gender boundaries, my interviewee underscored how discourses of nationalism (i.e., socialist construction) violently erased feminine markers of identity and fashion (and along with them certain experiences of femininity) that had preceded Maoist strictures about fashion and identity.

Today, the neoliberal forces that exalt the individual through the workings of market forces invest China with certain qualities that become highlighted as part of the national political project. While my older interview subjects spoke critically about the conformity of desires during the Maoist years, the younger women I interviewed exulted in the new cosmopolitan conformity within their reach. One was exhilarated by what we might call this space of neoliberal freedom with Chinese characteristics. The youngest of my interviewees (twenty-four at the time and a graduate student) 
confidently shared what she took as a difference between the older generation of women and her generation: "We care more about our own image, how [our images look] in others' eyes." Her remarks invoked the rhetoric of Deng's open-door policy of the late 1970s, which opened China to market forces for foreign trade and increased economic investment: "It's an open policy ... because we see more. Like in movies, TV ... they show us the foreign and American style, European style. And that's nice ... people always ... tend to go in the direction of the beautiful thing, you know." Her invocation of China's market economy couched in terms of the desire for the aesthetic situates beauty within a cosmopolitan framework of fashion.

In "Fashioning the Body in Post-Mao China" cultural studies theorist Xiaoping Li explains that "in contemporary China, a plurality of styles brought by global cultural flows provides individuals with unprecedented opportunities for self-representation and self-formation... . Fashion annihilates the suffocation of female beauty and desire in the Mao regime, and it may open up space for the rejuvenation of female subjectivity" (1998, 85 ). Li's speculation that fashion "may" create the opportunity for a resurgence of a gendered female subject turns into an aspirational reality for young Chinese women like my interviewee who feels giddy at the prospect of belonging to the global arena because of the deployment of a fashionable femininity in cultural and social spheres. ${ }^{3}$ This resurgence of youthful Chinese femininity recalls the 1930s "when women were supposed to be women. For the Nationalists, redefining the boundary between male and female was part of the process of sorting out the chaos into which Chinese society had descended" (Finnane 1996, 117). One of the significant differences for the twenty-first century is that with the rise of market socialism, the state and the market are no longer mutually exclusive oppositional forces confronting women in their quest for liberation (Wang 2001,69-70); instead, the postsocialist state has nimbly reinvigorated and condensed both the market and cultural value of fashion into the figures of young women dressed in a cosmopolitan modernity through their consumerist practices and performance of femininity. In other words, Chinese femininity has become a "modernist vision of youth as the emblem and consumer of pleasure in the market economy," foregoing and forgetting the unsettled times of the 1930s and the androgynous style of the Maoist revolutionary reformer (Zhang 2001, 145).

Consumption then becomes a crucial, yet contradictory, element of modern femininity. Transnational feminist theorist Lisa Rofel explains 
how consumption as a measure of freedom "is not just about pleasure"; it is "a post-socialist technology of the self by which Chinese young women and, by metonymic association, the Chinese nation, enable themselves to transcend the specificities of place and identity and be part of the 'world"' $(2007,118)$. And yet this entering the world through the fashion economy may come at a cost for some young Chinese women. One of my interviewees shared how her college-aged female students expressed their views for their futures. She said that the "so-so-looking" female students didn't think about being leaders in organizations or business; "most of the time they will choose to express their worries [about the future], but pretty girls, they talk about their dreams, the bright and beautiful dreams of the future." These differing sentiments are clearly informed by the affirmation from society—or lack thereof — that the women receive in relation to their appearance.

Even with its attendant costs this new vision displaces both the Nationalist woman and the female revolutionary with their twenty-first-century fashionable sisters and thus emphasizes the reorganization of the cultural logic of femininity. ${ }^{4}$ Although coined over a decade ago, the term "eaters of the rice bowl of youth" (qingchunfan) remains a salient formation in understanding female subjectivity in metropolitan China. Cinema studies scholar Zhang Zhen theorizes that "the robust image of vivacious, young female eaters of the rice bowl of youth symbolizes a fresh labor force, a model of social mobility, and the rise of a consumer culture endorsed by current official ideology-the 'democracy of consumption' promoted to prevent social unrest since the suppression of student movements in 1989" $(2001,132)$. These female "eaters of the rice bowl of youth" contribute to the almost festive sense of femininity across classes in urban China-buying cosmetics, having their hair cut/colored/curled, shopping for colorful clothes that reveal their female bodies. These young women build their sense of gendered and sexual identity through the consumption of products that rely on and produce a heightened performance of femininity. ${ }^{5}$ Responding to the call to consume as the action of a responsible postsocialist citizen, many young women go happily along the fashionable corridors of cosmetics and clothing displays enacting their good cultural citizenship by shopping to produce a state-sanctioned femininity.

In the current moment, fashion-including the feminized uniforms of the qipao and wedding dress - is seen as a welcome site through which gender distinctions are reinvigorated and femininity becomes a visible and 
vital component in China's growth on the international stage. One of my older interviewees explained how "in those days [of socialism under Mao] you had to live the way people wanted you to live," but in contemporary China "young women are free to look pretty, attractive, and there is nothing wrong with that." She ended with this summation: "Nowadays people don't attack you because you dress fancy." Her comments exemplify what Rofel calls "desiring China": "In postsocialist China cultural belonging, as connected to practices of desire, has replaced political struggles over class identity as the site on which citizenship is meaningfully defined, sought, and conferred or denied. Cultural citizenship creates 'desiring China' as a coherent entity to which one must prove one's allegiance" $(2007,94)$.

Fashion functions as a space for performing such cultural citizenship. Women's quotidian fashion in Shanghai and Nanjing bespeaks the impulse to belong to the new consuming class of metropolitan subjects. The two garments under discussion in this essay, in slightly different ways, underscore the power of cultural belonging through group markers of shared desire. In the one instance, the qipao of the service industry signifies Chinese feminized bodies earning their place within the market economy, and through that position they gain entrance to the circuitry of desire of which Rofel speaks. The wedding gown, while functioning on a less directly economic register, nonetheless signifies the bride's deliberate desire to participate in a fashionable formation of femininity that aligns desire and cultural belonging in the creation of a modern Chinese female subjectivity. Although older Chinese women are marginalized in this economy of youth, they acknowledge the heightened acceleration of the mechanisms for cultural and social belonging through desire, a desire not solely linked to consumerism but one intensely put into motion and visible in the consumer marketplace for femininity. This desire dresses itself literally and figuratively in the feminized uniforms, material expressions, and aspirations for an acceptable young, feminized beauty.

\section{Qipaos Serving the Nation}

To understand the significance of the qipao to today's service industry and its fashioning of femininity we must acknowledge the cultural valences the garment both invokes and masks. Much has been written about the qipao. A hybrid gown - with its roots in Manchu culture yet modified throughout its different incarnations by Han Chinese and Western influences - in the 
1920s it "signified the emergence of the 'modern' woman in China" with its less restricting cut in comparison with the traditional Han and Manchu garments (Clark 2000, 9). Social historian Antonia Finnane explains how "it derives its importance not from the numbers of women who wore it, although these certainly increased over time, but from who those women were. They were the women of an emerging middle class.... They were the female face of a progressive China and what they wore assumed a transcendental importance, signifying the hegemony of the modern" (1996, 111). A more form-fitting cut of the gown gained popularity in the 1930s. Representations of young women in qipaos adorned many advertising posters selling products ranging from cigarettes to pesticide sprays (Clark 2000, 14). ${ }^{6}$ The qipao was no longer merely a female version following the lines of the dynastic masculine cut; "the emphatic femininity of this garment" with its tailored bust, narrow waist and long side slits was appropriate to a time when the gender binary supported a republican nationalism that was taking shape (Finnane 1996, 117; 2008, 141).?

Additionally, this piece of feminized clothing sartorially inscribed a heterosexual gender divide marked with a modernizing middle-class sensibility in the face of a struggling nationalism. It became a garment of note during the mid-1950s dress reform campaign yet never fully revived (Finnane 2008, 217-20; Wu 2009, 111). After the communists came to power and especially during the Cultural Revolution (1966-76), the qipao was categorized as bizarre and decadent (Clark 2000, 21; Wu $2009,8)$ and was stigmatized as a sign of "stinking beauty" and feudalism (Finnane 2008, 236). Although the qipao was effectively erased from mainland China's sartorial arena until it began to resurface in the 1980s, Chinese women, paradoxically, became hyperconscious of fashion trends during the 1960s and 1970s so as not to transgress the rigid dress code of the revolution (Wu 2009, 2, 8). ${ }^{8}$ Even though some believed it would make a comeback (Wu 2009, 45), by the 1980s the qipao was relegated to "specialist designer evening wear" (Finnane 2008, 268) and the hospitality trade where it became an indelible marker of Chinese identity (Clark 2000, 53-54).

With its high-necked form-fitting silhouette and its side slits, the qipao now symbolizes a version of a public femininity tied to the nation. ${ }^{9}$ It marks the female body as a culturally specific object important to the national and cosmopolitan landscapes of the city, whether it is worn by young women from the countryside working in the hospitality trades, 
fashion-conscious women at nightclubs, or foreign women anxious to enter the space of a Chinese feminine, cultural symbolic. Finnane argues that the garment speaks of "a certain nostalgia for the 1930s and of a vague sense of the connection that qipao supplies with a generalized past" (1996, 125). In this way the qipao signifies its own politics of forgetting as it erases the communist revolution and its interpretation of the qipao as a marker of bourgeois class privilege, and instead writes into the fashion lexicon a romanticized image of leisure, sexual awareness, and gender relations. ${ }^{10}$ In his article "Contemporary Re-emergence of the Qipao" sociologist Matthew Chew suggests that "contemporary global and local cultural imagination have favoured certain symbolic meanings of the qipao, including sexiness, femininity, ethnic representation, cultural traditional representation and fashionability" $(2007,161)$. Thus the service industry version of the dress marks an uneasiness in cosmopolitan constructions of femininity as it simultaneously invokes a mythic prerevolutionary and depoliticized past marked by sophistication and luxury while it concurrently signals the pernicious national demand for female labor and consumption clothed in a highly mediated and overdetermined cultural form.

Private tailors and dress shops along the upscale boulevards in Nanjing, former capitol of China during the Nationalists' reign, sell readyand hand-made qipaos. In 2008 a shop near Hunan Lu, one of Nanjing's major shopping streets, displayed hand-embroidered silk qipaos selling for upward of the equivalent of three thousand U.S. dollars. Another shop on ZhongShan Lu carried colorful dresses on mannequins enticing the everyday shopper to enter and buy. Ironically, however, I never saw Chinese women on the street or in the shops in Nanjing wearing the long qipao (although there are several contemporary designers who have updated the qipao as a current fashion trend). ${ }^{11}$ Several of my Chinese colleagues told me that a Chinese woman might have one qipao to wear to weddings or other formal occasions, and even though that is becoming rare, there is still an intrinsic value given by Chinese society to the qipao as a signifier of authentic Chinese womanhood. ${ }^{12}$

Despite the availability of the stylish qipao, the only women regularly seen wearing the long, form-fitting version of the dress are service workers, especially young women who work in hospitality at restaurants and hotels. ${ }^{13}$ Fashion studies theorist Juanjuan Wu rightly suggests that these uses reduce the qipao's fashionability, diminishing its attraction to the younger, fashion-seeking generation of women $(2009,112)$. In this 
garment-now mass-produced, machine-made polyester versions rather than tailor-made, hand-sewn silk gowns-young women make available to the public a sexualized Chinese female body wrapped in a fashion that supposedly overwrites the economics of market capitalism with a memorializing of a past Chinese feminine elegance. The young women greeters and waitresses at restaurants and hotels embody the very spirit of global capitalism; they become the commodification of China, a gendered sartorial metonym for a sexualized submissive female ready to serve not only the tourist trade but also men and women of the newly affluent Chinese middle class who have the money and leisure time to spend on entertainment and travel. The service workers' dress and physical presentation signify the imagined beauties of an earlier period, bespeaking a femininity unfettered by mundane concerns (no household, career, or motherly responsibilities in evidence) and steeped in an unspoken but visually available sexual erotics and exotic otherness occupying the same temporal frame. ${ }^{14}$

The young women who wear these qipaos become signs of a particular type of femininity implicated in the formation of a desiring China; at the same time they become actors within its gendered national landscape. An escalating sense of glamour informs women's participation in Chinese citizenship in a metropolis like Nanjing or a megacity such as Shanghai. The desire to be part of this citizenry is not only maintained by those with money; many of the young female migrant workers who have moved into the urban space likewise strive to participate. Whereas such migrations once might have been driven by poverty or desperation, for many migration from the countryside to the city is now seen as what economics researchers Binbin Lou and coauthors call "a rite of passage ... or at least a great adventure" $(2004,239)$. Going out of their villages to arrive in the city, these young women from the rural provinces of China-commonly called "little country cousins"- have physically demanding low-end service jobs such as domestic worker and restaurant server. Yet they too want to participate in the newly available versions of fashionable femininity they see reflected in advertisements, in shop windows along Huahuai Lu in Shanghai's upscale shopping district, and on the bodies of their more financially and educationally well-off cosmopolitan sisters. So lest we forget, the qipao worn at work is not the permanent mark of identity of a service worker; rather it signals her ability to enter the consumer forum of national culture. The earnings of the qipao-clad service worker ushers her into the consumer citizenship of today's China, moving her out of the 
shadows of the rural/city divide and into the glow of a cosmopolitan femininity. In this case, assigned as a uniform by the business owner, the qipao embodies the commercial status of its wearer while also serving to mark the server's entrance into the sphere of cultural belonging.

In her insightful study of Chinese domestic workers, anthropologist Arianne Gaetano points out the complex aspirations that confront migrant women in the metropole. She explains how their participation alongside urban residents in the pastimes of shopping and local tourism allows them "to carve out their rightful place in the urban environment and identify them[selves] as consummate cosmopolitans" (2004, 71). However, such displays of desire must always be balanced against the filial demands placed on these young women. Obligations to send remittances to their families in the villages, to contribute to their brothers' educational funds, and to save for their own marriage dowries all put in jeopardy these young women's desires to participate in the new form of Chinese nationalism through consumption. In several of my interviews I heard expressions that underscored a growing social awareness of these competing demands for young women from the countryside. While their qipao-clad bodies act as symbols of a mythic femininity, these "little country cousins" hold a tenuous relationship to the sphere of citizenship they desire to share with their middle-class female peers; their aspirations to inhabit the feminine glamour in circulation - to embody the fashionable femininity of the moment-do not alleviate their precarious situations as migrant workers subject to governmental controls on their labor, residency permits, and access to the public sphere of femininity. The qipao symbolizes, then, a femininity laced with the discourses and dangers of commodification, autonomy, and vulnerability.

\section{Dressed in White}

Contemporaneous with the qipao in China's current grammar of cosmopolitan femininity and consumer culture is the white wedding gown. The white wedding gown is a hybrid import to China, a fashion style that initially referred to bridal wear from the United States and Western Europe but that entered mainland China via its popularity in Hong Kong, Taiwan, and Japan in the late 1980s (Gillette 2000, 192-94). ${ }^{15}$ This garment replaced earlier bridal clothing such as the skirted qipao, popular before the communist revolution, and the trousers and tunics worn up until the 
beginning of Deng's open-door period (Gillette 2000, 194). By the early 1990s, the white wedding gown, or hunsha, had become vastly popular wedding attire (Constable 2006) to such an extent that "while a qipao could be absent from a city wedding, Western wedding gowns became nearly indispensable" (Wu 2009, 118). Sutured into a discourse of romantic love, the white gown signifies a sense of female autonomy to young Chinese woman who read the performance of femininity through marriage as indicative of the cosmopolitan, liberated female self. ${ }^{16}$ Throwing off cultural traditions and donning a white gown marks a young woman's entry into an urban modernity unlike anything her mother would have experienced. This fashionable uniform connects her to a globalized imaginary of women as unfettered female subjects while concurrently encasing her in a heteronormative, patriarchal discourse that circumscribes her subjectivity. Echoing in tone although not style the prospects for empowerment and the condition of vulnerability inscribed in the qipao, the white wedding dress simultaneously symbolizes female independence and susceptibility to China's neoliberal postsocialist culture.

Every major city in China has several photography studios that specialize in wedding photography. The studios are wedding boutiques where young couples enter and select their "look" from catalogs of wedding photographs and the shop's rental gowns and tuxedos. Many of the studios offer location shots where the photographers accompany couples to outside locales selected for the romantic surroundings. There the couple enact their devotion to each other through a variety of poses and facial expressions. The gown reveals the young woman's entry into transnational circuitry of femininity, and the wedding portraiture memorializes the wearing of the gown. ${ }^{17}$ With both gown and portraits, her place in the romanticized consumer culture denoting Chinese citizenry is solidified. In her detailed analysis of wedding photography, anthropologist Nicole Constable discusses how women are commonly depicted as coy, sexy, and demure female subjects of the camera's gaze in wedding portraits (2006, 50). Constable points out a crucial paradox for women: "Unlike the Cultural Revolution images of model women that depicted them as strong, sturdy, in control, competent, and capable, and often minimized their feminine qualities, women's postures and positions in bridal and art photographs convey a sense of the woman as an object of beauty and sometimes of helplessness" $(2006,50)$. The woman's bridal performance and its photographic encoding tacitly confirm her femininity and the coterminous 
desire to be read through the imagery and discourses of love, romance, and physical intimacy only achieved by wearing the rented gowns. ${ }^{18}$

The photograph of the bride is the artifact that substantiates the erasure of the Maoist period in Chinese history much as the qipao beckons us to embrace a depoliticized history of glamour. On the one hand, the white gowns and bridal photographs are a demonstration of the new public nature of femininity and sexual politics, while on the other the gown and photos reinscribe a patriarchal view of femininity as indelibly marked by a restrictive heteronormative gender binary. Heterosexual desire is no longer chained to the service of the socialist state as it was the Maoist years; it is not relegated and regulated to a strictly reproductive discourse of nationalism, in contrast to the previous era, when heterosexual relationships were valued because they produced progeny for the health of the nation. The new relations now go hand in hand with the gendered discourse permeating various levels of Chinese society and most particularly images of young women's desirability and ability to desire. While the white gown inscribes a public semiotic rendering of their desirability according to a transnational cosmopolitan grammar of romance and gender, the gown also reinscribes these female subjects into a fashionable uniformity that marks them as enacting a publicly acceptable demonstration of femininity within the terms of a compulsory heterosexuality. ${ }^{19}$ In her article Constable remarks that "women present themselves in such [wedding] images as beautiful and sexual wives, not as state subjects and sturdy workers," and this "reflects a reappropriation of femininity and romance that is ... a statement about changing relationships to the state and market economy" $(2006,52)$. However, the iconography of romance and femininity represented by Chinese women in wedding gowns circulates both within a celebratory register of love and personal agency about whom to love and within the regulatory realms of heteronormative gender binary that is linked to the newly circumscribed consumer citizenship that the state demands.

\section{A New Day of Inappropriate Femininity?}

When the young middle-class Chinese woman steps into the restaurant where the qipao-clad server works, two versions of Chinese femininity meet. The young, middle-class urban woman, whose future white wedding gown ties her to the circuits of a global neoliberal economy of modernity, 
encounters her service worker peer's mythic performance of a feminized national and cultural subject clothed in qipao. A reconstructed past and an emerging modernity coexist, situating both women as "eaters of the rice bowl of youth," gendered players in a market economy drama of cultural politics. These women assert their Chinese femininity through a complicated set of desires for a more uniquely Chinese version of femininity yet one deeply striated by the politics of fashion and representations of womanhood screened through a nostalgia for China's past and the immediate processes of globalization, nationalism, and consumerism.

Read against the myopic representation of Chinese women as interchangeable female bodies in the machinery of global manufacturing, the qipao and the white wedding gown represent constituent aspects of a contested femininity. The femininity being produced and signaled by these fashions stretches previously static patriarchal boundaries of gender and sexual politics for women. As consumers and producers of femininity these women in their respective dresses are players in the life of the postsocialist state's economic and cultural agendas. Instead of inscribing a teleology of powerlessness onto these garments and the women who wear them, we might read these embodiments of a fashionable, albeit commercialized, cultural femininity as subtly setting in motion the process of mimicry that postcolonial theorist Trinh T. Minh-ha has theorized as a strategy of displacement and possibility. Trinh's theorizing of the "Inappropriate Other/ Same" expresses some of the tension these two invocations of Chinese femininity produce through their coexistence. Situating her theorizing within the field of fashion, Trinh's "Inappropriate Other/Same" dresses to "affirm that 'I am like you' while persisting in her difference; and that of reminding 'I am different' while unsettling every definition of otherness arrived at" (Trinh 1991, 74). For the qipao-clad service worker who enacts a form of prescribed, sexualized commercial femininity, her embodiment opens up the possibility for her own economic and aspirational powers within the metropole to exceed the mythic cultural significations assigned to the qipao. In this way, her "Inappropriateness" signifies "I am like you in that I don the dress expected of me by the boss and economy, but I am different from what you expected and am not a stagnant commodity in consumer society." Similarly, wearing the white wedding gown initiates our expectations of the bride's performance while this embodiment troubles the neoliberal script of female agency as the bride strives to redefine her subjectivity against that nation-state's agenda to marshal femininity for its 
own economic benefit. Her "Inappropriateness" suggests "I am like you in that I wear the dress that situates me in the transnationally comfortable story of romance and heterosexual marriage, but I am different because of my generation's tentative exploration of what an empowered femininity might look like." This slippage - the inappropriateness-in the meanings associated with both these figures writes into the cultural and social landscape women who are aspiring to be actors in the cosmopolitanism of China, and yet because of the Chinese context from which they emerge, their stories of femininity and agency have yet to be written from within (and against) the dynamic national and transnational registers that they are encountering and provoking.

The femininity visible through these two fashion statements is neither inherently negative nor necessarily obstructive to different configurations of femininity. Yet the meanings attached to both the qipao and the wedding gown - two signifiers of a consuming nationalist production of femininity - do raise questions about how expressions of divergent forms of Chinese female subjectivity will emerge from an atmosphere where consumer culture functions as the primary arbiter of femininity. ${ }^{20}$ Xiaoping $\mathrm{Li}$ captures the conundrum confronting young women in China: "Fashion and other body techniques enable the Chinese to join modernity symbolically; can that symbolic entry (or the gap between manufactured dreams and material existence) prompt any substantive action?" (1998, 88). Can the gendered binary, heteronormativity, and mythic cultural nationalism produced and circulating through a consuming desire for modernity give way to other socially responsive and critically engaged representations of femininity, sexuality, and subjectivity? It may be a "new day" for many young women in China, as my interviewees decreed, but this day is clothed in paradoxes produced when consumerism gains supremacy in the construction of female subjectivity. Although it is too soon to know exactly how Chinese femininity will dress itself in the future, it is clear from the sartorial signs that Chinese women, in the words of one of my interviewees, are thinking about their gender identity and self-expression through fashion and "trying their best to be independent" while being painfully aware of the representational and societal pressures that mitigate such expressions. 


\section{Acknowledgments}

Thanks to the WSQ anonymous reviewers for their useful insights, and to Beth, who is my constant source of support.

Sally E. McWilliams is professor and chair of women, gender, and sexuality studies at Portland State University. Her research focuses on representations of gender and sexuality in contemporary international women's literature, feminist/queer narrative strategies, and transnational feminist activism.

\section{Notes}

1. While I am aware of the numerous and diverse ethnicities populating mainland China, my analysis focuses on women from the dominant Han group.

2. The militarized look of women's clothing during the early years of the People's Republic of China is explored in Finnane 2008, chapters 8 and 9; Wu 2009, chapter 3; and Chen's "Dressing for the Party."

3. During the 1930s the Nationalist Party was consolidating its power in the aftermath of the warlord period; this consolidation employed the recreation of a gendered social divide where women were to be feminine, men masculine. The New Life Movement of 1934 underscored women's roles as wives and mothers. This heteropatriarchal divide was enforced through a sartorial separation in which the qipao gained what Finnane calls its "emphatic femininity” and its close association with Chinese modernity $(1996,117)$. Interestingly at the same time the women in the underground Communist Party were sporting androgynous pants and jackets.

4. Rofel helps us understand the enactment of desire: "Consumption is about embodiment, embodying a new self. At the heart of this embodiment is desire. A properly cosmopolitan self is supposed to be desirous and this desire is supposed to be open and unconstrained" $(2007,118)$.

5. Political scientist L. H. M. Ling understands this femininity as "an implicitly closed, localized, service-based, and socially regressive hyperfemininity" (1999, 278). The Chinese government, however, struggles over the unbounded aspects of such representations of femininity, as was evidenced in the government's recent attempts to curtail certain sexualized imagery of young women by canceling the popular Super Girl on CCTV.

6. Fashion historian Hazel Clark also notes that the overseas circulation of these posters equated Chinese femininity with this style of dress $(2000,14)$.

7. Finnane explains that the qipao was introduced as a one-piece loose-fitting "banner gown" of Manchu origin during the Qing dynasty $(1996,106)$; Wu 
sees it as connected to Han men's gowns $(2009,110)$. The androgyny of the qipao came to an end during the late 1920s as tailors began to cut the fabric along the bias along with adding darts (see Finnane 2008, 218; Clark 2000, 16, 39; Wu 2009, 108).

8. Clark explores how the qipao developed in Taiwan and overseas Chinese communities (2000, 23), while Lee and Chung examine Singapore's fashion scene (2012). In Annie Chan's sociological discussion of the qipao in Hong Kong, she writes that the qipao "has changed from representing sophistication and modernity [in Hong Kong] to representing Chinese-ness, servility, and kitsch" (2000, 308).

9. Matthew Chew argues that it is not a form of national dress, but rather a cultural marker (2007, 148-49). While it may not be inscribed politically as the national dress of China, the qipao is semiotically inscribed with both a national and cultural valence in the popular imagination. Wu writes that Westerners have come to associate the dress as a national symbol of China, while she also recognizes that its status as a national symbol is unstable and problematic because of its connotation as a marker of an ethnocentric nationalism $(2009,114,119,124-26)$. Hongmei Li's essay on the wearing of qipaos by "ceremonial misses" during the 2008 Beijing Olympics underscores the symbolic importance of the dress within an international arena. While Chew argues that these sorts of qipaos, along with those worn as hotel and restaurant uniforms, should be relegated to the category of costume and not fashion $(2007,148)$, I see these manifestations of qipaos as crucial markers of femininity through fashion in the consumer economy of China.

10. Postmodern scholar Arjun Appadurai's phrase "nostalgia without memory" (1996) expresses the core paradox of the qipao: it is a garment that signifies the cultural desire for a romanticized and sanitized past (cleansed of national politics) that never existed.

11. Chew (2007) and Wu (2009) provide more discussion on fashion designers' incorporation of qipao-like dresses in their couture. Clark (2009) discusses the two luxury brands Shanghai Tang and Blanc de Chine and their refashioning of Chinese styles, history, and imagery.

12. This interpretation is favored by foreigners who read the qipao as the quintessential gendered cultural marker. For example, while I was in Nanjing the wife of an American visiting professor had a qipao made for herself-a symbol of having "been to China," she explained to me. In this act of performing Chinese femininity by owning and wearing the qipao, the foreign woman partakes in a consumerist form of Orientalizing: it is only by having the garment marking a time/place/culture outside her U.S. narrative of fashion and modernity does the qipao have value as its cultural meaning crosses transnational spaces. Anthropologists Jones and Leshkowich (2003) pursue the 
politics of Orientalism as it is put into play when the global fashion industry defines Asian fashion.

13. I would be remiss in not mentioning the inclusion of the red qipao as one of the gowns an urban Chinese bride incorporates into her wedding attire. Wu dates this fashion occurrence to the 1990s. Like the white and evening gowns that frame her wedding regalia, the young bride purchases but more often rents a red qipao to mark her traditional cultural belonging. This garment links her to a previous Chinese epoch, thus invoking a seemingly depoliticized yet highly romanticized Chinese historical moment within the present time. This romanticization of the gown resonates with its service industry incarnation, as both conjure up a nostalgia for a fantastical past.

14. Chew argues that "a particular kind of sexiness has been increasingly constructed into the popular imagination of the qipao since the 1970s. It is an unsubtle kind of sexiness that relies on the baring of flesh and that caters to tourist and male gazes. An example is qipaos with long slits that are used as work uniforms in restaurants and nightclubs" $(2007,159)$. Communications scholar Hongmei Li's analysis of Olympic "misses" goes in another direction, pointing to a "subtle sexuality" $(2011,377)$.

15. Clark reports that Western wedding gowns were included in a national fashion show in Beijing as early as 1981 (2000, 55).

16. The appropriation of the Western white wedding gown is not accomplished in terms of a simple one-to-one translation from the West to Chinese context but is rather more postmodern in its turn as the Chinese construct their own sense of modern identity from wearing it. See Jin Yihong's essay for further elaboration on this point. Anthropologist Maris Boyd Gillette's analysis of Hui women in Xi'an expands on the idea of young women being able to assert their consumer awareness when renting gowns (2000, 203).

17. Cultural anthropologist Bonnie Adrian (2003) demonstrates the complexity of this transnational circuitry. She points out that regarding the bridal photography industry, while Taipei photographers look to the United States for fashion trends, "bridal photographers in the People's Republic of China look to Taiwan" (16).

18. The cultural tradition of handing down one's white wedding gown from mother to daughter that happens in some U.S. households has not been created in China.

19. Gillette's (2000) case study assesses the tension between conformity and agency for a Hui bride by analyzing how the bridal attire demonstrates her autonomy from the controls of both religious institutions and the central state government.

20. My query is echoed in Hongmei Li's ideas about femininity in a post-Beijing Olympics China: "It remains to be seen whether this passage into modernity 
was accomplished at the expense of the reiteration of a hybrid of feminine stereotypes from China and the West, or whether the misses and cheerleaders have opened a space for agency and slightly progressive sexual politics" $(2011,387)$.

\section{Works Cited}

Adrian, Bonnie. 2003. Framing the Bride: Globalizing Beauty and Romance in Taiwan's Bridal Industry. Berkeley: University of California Press.

Appadurai, Arjun. 1996. Modernity at Large: Cultural Dimensions of Globalization. Minneapolis: University of Minnesota Press.

Chan, Annie Hua-Nung. 2000. "Fashioning Change: Nationalism, Colonialism, and Modernity in Hong Kong." Postcolonial Studies 3(3):293-309.

Chen. T. 2001. "Dressing for the Party: Clothing, Citizenship, and GenderFormation in Mao's China." Fashion Theory: The Journal of Dress, Body, and Culture 5(2):143-71.

Chew, Matthew. 2007. "Contemporary Re-emergence of the Qipao: Political Nationalism, Cultural Production, and Popular Consumption of a Traditional Chinese Dress." China Quarterly 189:144-61.

Clark, Hazel. 2000. The Cheongsam. Oxford: Oxford University Press.

- 2009. "Fashioning 'China Style' in the Twenty-First Century." In The Fabric of Cultures: Fashion, Identity, and Globalization, ed. E. Paulicelli. H. Clark. London: Routledge. 177-93.

Constable, Nicole. 2006. "Nostalgia, Memory, and Modernity: Bridal Portraits in Contemporary Beijing." Visual Anthropology 19:39-55.

Finnane, Antonia. 1996. "What Should Chinese Women Wear? A National Problem." Modern China 22(2):99-131.

- 2008. Changing Clothes in China: Fashion, History, Nation. New York: Columbia University Press.

Gaetano, Arianne. 2004. "Filial Daughters, Modern Women: Migrant Domestic Workers in Post-Mao Beijing." In On the Move: Women in Rural-to-Urban Migration in Contemporary China, ed. A. M. Gaetano. T. Jacka, 41-79. New York: Columbia University Press.

Gillette, Maris Boyd. 2000. Between Mecca and Beijing: Modernization and Consumption Among Urban Chinese Muslims. Stanford: Stanford University Press.

Li, Hongmei. 2011. "The Gendered Performance at the Beijing Olympics: The Construction of the Olympic Misses and Cheerleaders." Communication Theory 21: 368-91. 
Jin, Yihong. 2007. "Rethinking the 'Iron Girls': Gender and Labor During the Chinese Cultural Revolution." In Translating Feminisms in China, ed. D. Ko. Wang, 188-214. Oxford UK: Blackwell.

Jones, Carla, and Ann Marie Leshkowich. 2003. "Introduction: The Globalization of Asian Dress: Re-Orienting Fashion or Re-Orientalizing Asia." In Re-Orienting Fashion: The Globalization of Asian Dress, ed. S.

Niessen, A. M. Leshkowich, and C. Jones. Oxford, UK: Berg.

Lee, Chor Lin, and May Khuen Chung. 2012. In the Mood for Cheongsam.

Singapore: Editions Didier Millet Pte..

Li, Xiaoping. 1998. "Fashioning the Body in Post-Mao China." In Consuming

Fashion: Adorning the Transnational Body, ed. A. Brydon. S. Niessen. Oxford $\mathrm{UK}$ : Berg.

Ling, L. H. M. 1999. "Sex Machine: Global Hypermasculinity and Images of the Asian Woman in Modernity." positions: east asia cultures critique 7(2):277-306.

Lou, Binbin, Zhenzhen Zheng, Rachel Connelly, and Kenneth D. Roberts. 2004. "The Migration Experiences of Young Women from Four Counties in Sichuan and Anhui." In On the Move, ed. A. Gateano. T. Jacka, 207-42. New York: Columbia University Press.

Rofel, Lisa. 2007. Desiring China: Experiments in Neoliberalism, Sexuality, and Public Culture. Durham, NC: Duke University Press.

Trinh, T. Minh-ha. 1991. When the Moon Waxes Red: Representation, Gender, and Cultural Politics. New York: Routledge.

Wang, Jing. 2001. "Culture as Leisure and Culture as Capital." positions: east asia cultures critique 9(1):69-104.

Wu, Juanjuan. 2009. Chinese Fashion: From Mao to Now. Oxford: Berg.

Yang, Mayfair Mei-hui. 1999. "From Gender Erasure to Gender Difference: State Feminism, Consumer Sexuality, and Women's Public Sphere in China." In Spaces of Their Own: Women's Public Sphere in Transnational China, 35-67. Minneapolis: University of Minnesota Press.

Zhang, Zhen. 2001. "Mediating Time: The 'Rice Bowl of Youth' in Fin de Siècle Urban China.” In Globalization. ed. A. Appadurai, 131-54. Durham NC: Duke University Press. 